\section{Razões técnicas e efeitos simbólicos da incorporação do "progresso tecnocientífico": reprodução assistida e adoção de crianças*}

Martha Ramírez-Gálvez ${ }^{1}$

Resumo: As opções tecnológicas são também políticas, mas as implicações políticas das opções tecnológicas são obscurecidas por discursos, práticas e decisões que se apresentam como razões estritamente técnicas. Ao considerar o caso da reprodução assistida (RA), observamos que a busca pelo desenvolvimento técnico responderia, em principio, a razões meramente técnicas que buscariam a satisfação de um desejo "natural e atávico" de vivenciar a experiência corporal da gravidez, parto e amamentação, ancorado na naturalização do desejo de reprodução. No entanto, tais questões são reconsideradas neste artigo, em função da especificidade e singularidade do campo. Para a realização de tal análise, se coloca em perspectiva o campo da RA e de adoção de crianças. Resultados preliminares indicam que o uso de procedimentos de RA tiveram outros desdobramentos para além da consecução de um filho, ganhando um novo nicho de mercado: a função simbólica de elaboração de luto pelo filho biológico, considerada necessária para o amadurecimento do projeto de adoção de crianças.

Palavras-chave: Reprodução Assistida, Biotecnologia, Adoção, Mercado.

\section{Introdução}

T rata-se aqui de apresentar algumas ideias acerca de uma pesquisa na qual se analisa o consumo de tecnologias reprodutivas conceptivas como expressão da incorporação do progresso científico. Esta pesquisa atenta para as questões ligadas ao consumo de tecnologias de ponta que visam à adequação dos corpos a modelos convencionais de família. Nesse panorama, cabe perguntar em que medida a ampla divulgação na mídia sobre o uso dessas tecnologias, a fetichização da transmissão genética, o rápido crescimento de centros de RA no Brasil e a realização de campanhas para popularizar o bebê de proveta podem estar provocando alguns efeitos no processo de adoção de crianças.
Recebido:

11/04/11

Aprovado:

07/12/11

1. Professora adjunta, do Departamento de Ciências Sociais da Universidade Estadual de Londrina.

E-mail:

marthacerg@gmail. com
* À memória de
Alejandra Rotania,
parceira de trocas
e grande entusiasta
dessa proposta de
colocar em relação
a reprodução assis-
tida e a adoção de
crianças.
Este artigo faz par-
te do projeto de
pesquisa "Sujei-
ções tecnológicas
e identidade na
Reprodução Assisti-
da", financiado pelo
CNPq. Uma versão
preliminar deste ar-
tigo foi apresentada
no 33o Encontro
Anual da Anpocs,
Caxambu, 2009. 
2. O uso de tecnologia reprodutiva também é social, mas, ao usar aspas para indicar a opção pela adoção de crianças, queremos, simplesmente, assinalar esta com uma possibilidade de ter fiIhos não biológicos, sem apelo ao uso de tecnologias médicoreprodutivas.
Parte-se do suposto de que toda opção tecnológica é também política, dimensão que frequentemente é obscurecida por discursos, práticas e decisões que se apresentam como fundadas em razões "estritamente técnicas" (SANTOS, 2008). $\mathrm{Na}$ análise da relação entre as mudanças tecnológicas e sociais, Beck e BeckGernsheim observam diversas perspectivas, entre as quais aquelas que, por um lado, focalizariam o "determinismo tecnológico" e veriam a tecnologia como um destino que se autodefiniria, tanto em termos da inevitabilidade de sua aplicação, quanto nos termos em que ela deveria ser aplicada. Por outro lado, numa vertente de "reducionismo social", conceber-se-ia que seriam os usuários a decidir aplicá-la ou não e como fazê-lo. Todavia, uma vertente mais recente abordaria a tecnologia como um processo em espiral, que: "parece a la vez producto e instrumento de las necesidades, los intereses y los conflictos sociales" (BECK \& BECK-GERNSHEIM, 2003, p. 247).

Alinhamo-nos a uma perspectiva que busca atentar para a função da tecnociência como construtora ou produtora de significados, discursos e representações sociais, em contraposição à visão que pensa o desenvolvimento tecnocientífico como mera resposta às demandas do mundo contemporâneo. A dimensão ou a abordagem de consumo de certas tecnologias, associadas a estilos de vida, torna-se estratégica para observar as concepções do universo tecnológico tido, na maioria das vezes, como inerentemente progressivo e benéfico. No entanto, é importante analisar tais questões na sua especificidade e singularidade, tendo aqui como estratégia analítica colocar campos em perspectiva para observar os desdobramentos, usos inesperados da tecnologia ou, desvios de função. Embora com propósitos diferentes, a ideia de "desvio de função" usada aqui é inspirada em Kasper (2005), para considerar as virtualidades de uso de um artefato tecnológico, na qual é possível pensar o deslocamento de um objeto (no caso, da tecnologia reprodutiva) para um novo contexto ou com efeitos em outro contexto.

Neste artigo, focalizamos o caso da reprodução da vida humana no laboratório e das implicações, modificações ou efeitos concomitantes que tal oferta tecnológica traz para o que chamaremos como "opção social"2 à infertilidade involuntária. Isto é, explorar as implicações de soluções médico-tecnológicas (com o uso da Reprodução Assistida) que substituiriam e/ou deslocariam soluções sociopolíticas (como a adoção de crianças). Ao pensarmos em efeitos concomitantes, colocando em perspectiva campos que têm em comum o fato de serem soluções para a infertilidade involuntária, estamos apontando a maneira como as técnicas são usadas ou as influências das mesmas em campos similares, focalizando, assim, assuntos que não estão mais reduzidos à esfera da competência técnica e sim social ou política. Essa forma de conceituar a analisar esse campo se opõe à visão da ciência como um corpo abstrato de conhecimentos, 
desvinculado da sociedade e da cultura (CROISSANT \& RESTIVO, 1995).

Sendo um dos focos de análise deste artigo as razões técnicas que aparentemente orientariam o uso de algumas técnicas de Reprodução Assistida (RA), na primeira parte focalizamos a análise de algumas das discussões entre especialistas em reprodução humana, acerca do uso de algumas tecnologias em detrimento de outras. Essas discussões aconteceram durante o V Congresso Brasileiro de Reprodução Assistida, realizado em Campos de Jordão (SP), em 2001. Na segunda parte do artigo, focalizamos os possíveis desdobramentos que o uso de tecnologias reprodutivas conceptivas teria, ao considerar como elas se instauram no campo da adoção de crianças não em termos técnicos, mas simbólicos. Para tal efeito, as considerações dessa parte estão fundamentadas na análise de 25 processos de habilitação para adoção (do Fórum de Santo Amaro, SP), na observação etnográfica de três grupos de apoio a adoção do Estado de SP (dois localizados em São Paulo, capital, e um em Campinas), assim como em entrevistas informais realizadas com frequentadoras/es e voluntárias/os desses grupos.

2. Tecnologia como progresso e responsabilização dos indivíduos na saúde e nas suas escolhas

A Reprodução Assistida se refere a uma série de métodos que colocam a intervenção médico-tecnológica como condição para a ocorrência de uma gestação. O acelerado desenvolvimento dessas tecnologias, o crescimento de clínicas e centros que oferecem esses serviços no país, assim como a rápida aceitação do uso de tecnologias na criação da vida humana, levam, necessariamente, a ponderar o lugar da ciência moderna e da tecnologia no mundo contemporâneo, considerada como intrinsecamente progressiva e benéfica na tradição lluminista (OUDSHOORN, 1994).

Como lembram Beck e Beck-Gernsheim (2003), com a industrialização, os indivíduos começaram a ser os principais responsáveis pelo seu próprio sustento, obtido a partir de seus méritos pessoais. A vida não é mais uma dádiva Divina, mas uma propriedade individual, sendo cada um responsável pela sua autogestão. A preservação da saúde, nessas novas circunstâncias, ocupa um lugar de destaque: o valor do corpo e tudo o que é relacionado ao mesmo é ressaltado, uma vez que uma boa saúde e um corpo em condições ideais são a única garantia, ao longo de toda a vida. A saúde atinge um significado transcendental: “... sin ella, todo lo demás es nada" (DAELE, apud BECK \& BECK-GERNSHEIM, 2003, p. 251). Tal condição coloca duas questões importantes para pensar nosso objeto de interesse: o que se configura como doença, a partir de certo momento do desenvolvimento tecnológico; e as possibilidades de intervenção que se abrem 
3. Em 2009, o Dr. Adbelmassih foi acusado judicialmente por crime sexual, manipulação de óvulos indevida e sonegação fiscal. Desde então, o Conselho Federal de Medicina suspendeu seu registro profissional por tempo indeterminado. a partir, digamos, de uma redefinição de processos que passam a ser passiveis de intervenção tecnológica, como é o caso da infertilidade.

Com a difusão das biotecnologias, nas quais, à tecnologia, se integram a medicina, a biologia e a genética, a maleabilidade da vida ganha dimensões importantes. Trata-se da possibilidade de o homem inventar a si mesmo, colocando como preocupação a seleção de características e capital genético da descendência. Como afirma Rotania (1995), a RA traz um espiral de indagações tecnológicas e manipulações, decorrentes do interesse da qualidade do embrião, da procura da "perfeição biológica", ancorada em uma extrema racionalização da procriação e em um acelerado desenvolvimento biotecnológico.

Aspectos instigantes desse universo surgem a partir da fragmentação do processo reprodutivo e da redução do mesmo a níveis moleculares, integrando complexos empreendimentos contemporâneos de domínio dos processos biológicos, nos quais a aliança entre tecnociência e capital configura novos cenários para a afirmação de valores e modelos tradicionais sobre gênero e reprodução.

Contudo, se as inovações tecnológicas nessa área são justificadas por estarem ao serviço de "nobres causas" - como a de possibilitar uma progressão tida como normal e natural da realização conjugal - elas também produzem efeitos materiais em relação a valores culturais, tais como o enaltecimento do progresso científico e tecnológico ligado à ideia de bem-estar.

O conceito de embodied progress (FRANKLIN, 1997), usado para designar o processo no qual o progresso científico-tecnológico é incorporado através de práticas como a RA, torna-se de grande utilidade analítica, uma vez que permite pensar o avanço tecnológico como valor cultural associado, no caso da RA, a valores tradicionais de hereditariedade, exacerbados com o conhecimento da genética e da biologia da reprodução. Da perspectiva de Beck e Beck-Gernsheim, ainda que suas reflexões sejam orientadas ao uso da terapia genética, podemos retomar o conceito de "doentes-sadios" para pensar o caso da infertilidade. Uma doença, como considera o Dr. Roger Adbelmassih (1999), cujo único remédio é uma gravidez.

Doravante, ao discutir o caso específico do uso de tecnologias reprodutivas no Brasil, privilegiamos as referências ao especialista Roger Adbelmassih por ele ter pautado, em grande medida e até recentemente ${ }^{3}$, o campo da RA no país. As estratégias de divulgação usadas pela clínica do Dr. Abdelmassih não são representativas do resto das clínicas nacionais, nem consideramos que suas práticas sejam generalizáveis. No entanto, dada a diversidade e a cobertura de tais estratégias, as mesmas se tornaram singularmente expressivas para analisar a produção do discurso sobre RA no panorama nacional. 
Segundo Adbelmassih (1999), o desejo de reprodução é um imperativo genético, cuja frustração ocasionaria o drama dos casais sem filhos, que sofreriam abalo no nível pessoal, familiar e social. A pressão social ocasionaria uma profunda dor nas pessoas ou nos casais inférteis, ao não poderem responder à prescrição da necessidade de filhos para a consolidação de uma família. A infertilidade, afirma esse especialista, não se manifesta com sintomas, dor física, nem constitui uma ameaça à vida, porém ocasiona um "golpe violento" à personalidade do indivíduo, para o qual o "único remédio é uma gravidez" (1999, p. 21).

A superação da dor, mediante a transformação do sonho em realidade, somente se tornaria possível com o esforço da ciência para vencer as diferentes causas da infertilidade. Mais especificamente, com o esforço que as diferentes clínicas, principalmente a desse especialista, realizam para o desenvolvimento de técnicas mais efetivas que permitiriam, com mais sucesso, a chegada do anelado filho. Os parâmetros de sucesso, amplamente divulgados por esse centro, afetavam os procedimentos a serem implementados em outras clínicas e, como em qualquer contexto, a competição pelo mercado.

O número de casos atendidos e o uso de alta tecnologia por parte do centro marcaram o ritmo do crescimento da RA não só no país, como também na América Latina. Faz-se pertinente, aqui, a análise do campo científico como um local de concorrência, no qual se coloca em jogo o monopólio da autoridade científica, definida pela capacidade técnica e o poder social (BOURDIEU, 1994). Isto é, a competência científica que permite falar de maneira "autorizada e com autoridade", dá-se por via da acumulação de capital tecnológico e simbólico.

Contudo, a adoção de técnicas ou procedimentos-padrão não necessariamente corresponde a "escolhas científicas" ou a razões técnicas, e sim a estratégias políticas de investimentos que conduzam à maximização do lucro, tanto científico, quanto econômico. "Os dominantes são aqueles que conseguem impor uma definição de ciência segundo a qual a realização mais perfeita consiste em ter, ser e fazer aquilo que eles têm, são e fazem" (BOURDIEU, 1994, p. 128). Para observar mais claramente tal questão, fazemos referência, a seguir, a uma discussão sobre o uso de algumas técnicas e procedimentos utilizados na RA, que acontecera durante um congresso de especialistas no campo.

3. Injeção Intracitoplasmática de Espermatozóide (ICSI) ou Fertilização In vitro: razões técnicas?

As técnicas utilizadas na RA são descritas e classificadas como de baixa e alta complexidade. As primeiras seriam usadas para corrigir a infertilidade que "não é muito ruim" e a infertilidade sem causa aparente. O uso de técnicas simples 
4. O PGD não é uma técnica conceptiva, mas envolve a micro-manipulação de gametas para selecionar os préembriões a serem implantados no útero.

5. A relação custo/ beneficio tem, no ver de Berlinger e Garrafa (2001), um valor relativo, uma vez que os custos e benefícios nesse tipo de intervenção envolvem muitas pessoas e inclusive gerações futuras. No entanto, para efeitos da discussão que estava sendo ali colocada, essa relação parecia ser colocada em termos das ponderações a serem realizadas entre a complexidade da técnica, seus custos e os resultados obtidos. ou de baixa complexidade, nesse último caso, seria controverso, pois, para alguns especialistas, o fato de não se conhecerem as causas da infertilidade seria motivo para usar técnicas mais complexas. As técnicas de alta complexidade são aquelas nas quais se realiza a micro-manipulação de gametas, tais como a Fertilização In Vitro (FIV), a Injeção Intracitoplasmática de Espermatozóide (ICSI), e o Diagnóstico Genético Pré-implantacional (PGD) 4 .

Definir em quais casos utilizar certas técnicas foi um dos temas debatidos durante o V Congresso Brasileiro de Reprodução Assistida e o II Congresso Paulista de Medicina Reprodutiva, realizado em Campos de Jordão (SP), em agosto de 2001. Um dos trabalhos apresentados na Mesa Redonda "Reprodução de alta complexidade" mostrou comparativamente o desempenho entre a FIV e a ICSI, com o intuito de definir qual dessas técnicas seria a mais conveniente de ser usada, em termos de custo/benefício ${ }^{5}$. A FIV, desenvolvida em 1978, teria sido desenhada para os casos de obstrução tubária bilateral e de esterilidade sem causa aparente. A ICSI, desenvolvida em 1992, seria indicada para infertilidade masculina grave, uma vez que permite tomar os espermatozóides no epidídimo ou, na falta deste, células espermátides, que são injetadas diretamente no óvulo para realizar a fecundação.

A palestrante, após indicar que, na sua clínica, a tendência é abandonar a FIV, passou a indagar seus colegas de mesa acerca da prática dominante em seus respectivos centros. Tal questão seria motivadora de uma discussão maior. Um dos especialistas indicou que a ICSI começou a ser usada como um modelo experimental humano - como lembra Beck (1998), a implementação como experimento -, afirmando que a tendência na sua clínica é a de privilegiar técnicas que tenham mais tempo de uso e que, portanto, apresentam maior casuística, o que permitiria fazer avaliações mais confiáveis. Em função de tais critérios, privilegiam o uso da FIV.

Outro dos especialistas que integrara a mesa manifestou usar a FIV como procedimento padrão, argumentando que, se a FIV e a ICSI apresentam taxas de fecundidade similares, deveria ser usada aquela técnica menos invasiva e que mais se aproxime ao modo como a fecundação acontece "naturalmente". Uma visão bem diferente foi manifestada por outro especialista, atuante na maior clinica de RA do país - a clínica do Dr. Roger - que afirmou a opção de usar somente ICSI porque suas pacientes pagam um preço elevado por esses procedimentos, o que justificaria o uso de uma técnica que, além de ser mais moderna, considera mais eficaz.

Tal discussão coloca em evidência a existência de diferentes tendências e lógicas que orientam as decisões em relação às técnicas e aos procedimentos adotados pelos profissionais da RA. Entre alguns deles, manifestou-se certa desconfiança 
por desconhecerem as consequências de algumas técnicas de uso recente e ainda não suficientemente avaliadas. A ponderação dos riscos e de uma maior cautela quanto à aplicação de técnicas experimentais pareceriam estar presente nessa perspectiva, na qual haveria menor receio com o uso daquelas que deixam atuar ou imitam mais fielmente a natureza.

Por outro lado, identifica-se outra lógica operando nesse debate, na qual pareceria haver uma aposta cega na tecnologia de ponta. Considera-se que, pelo fato da ICSI ser de última geração, seria necessariamente melhor ou, senão, seu alto custo deveria justificar o uso ou aplicação, pelo menos entre uma parcela abastada da população. No fundo, nessa perspectiva - à que interessa dar relevância por ser defendida pelo especialista da maior clínica que pautava o mercado de serviços de RA no país e na América Latina -, o que se compra e se vende é o acesso a tecnologias mais modernas e sofisticadas, mesmo que os resultados sejam similares a outros procedimentos mais convencionais ou "tradicionais" e, ainda, sem conhecer os riscos das mesmas, em longo prazo.

O uso generalizado da ICSI no centro desse especialista não é justificado do ponto de vista técnico e, sim, econômico ou do acesso à sofisticação tecnológica que oferecia essa clínica. As pacientes ou os casais pagariam caro por novidades tecnológicas que, teoricamente, as/os colocaria mais próximas/os de realizar o sonho reprodutivo ou, poderíamos considerar, pela distinção que Ihes atribui o uso de tecnologias de ponta ou de última geração. Interessa notar que um dos aspectos mais enfatizados nos catálogos e nas páginas eletrônicas de algumas clínicas de RA é o fato de as mesmas contarem com o que há de mais recente no universo tecnológico (RAMíREZ-GÁLVEZ, 2003), num certo "encantamento pelo conhecimento gerado e suas múltiplas, variadas, possíveis e reais aplicações" (ROTANIA, 1996, p. 173). Nesse sentido, parece que vamos indo ao encontro e à consagração do inédito, momento em que a aceleração do desenvolvimento tecnológico introduz o menosprezo pelo velho e até pelo atual (SANTOS, 2000).

A questão, como manifestaram alguns especialistas durante esse evento, não seria a de desestimular o uso de tecnologias reprodutivas, mas sim de fazer avaliações diagnósticas mais criteriosas que possibilitem o uso de procedimentos menos invasivos, mais baratos e de menor risco, não só para as mulheres, como para as crianças e para as futuras gerações. A falta de uma adequada avaliação levaria ao uso apressado de complexos procedimentos e técnicas que, como indica o especialista Hallak (2000), criam a falsa imagem de que gerar um filho de modo convencional é complicado e obsoleto.

As questões anteriores colocam em evidência as fraturas dentro do campo de especialistas. Essas divergências indicam não só diferenças na perspectiva de saberes ou enfoques, como também trazem à baila um campo de disputa 
de poder e de autoridade. Na disputa de mercado, por parte de algumas clínicas, as implicações e os riscos do uso de certas técnicas e procedimentos seriam banalizados.

\begin{abstract}
A importância da avaliação do homem e dos tratamentos andrológicos tem sido questionada, mesmo sabendo-se que doenças graves podem ser encontradas em homens inférteis e que são apenas descobertas por meio de uma avaliação cuidadosa e abrangente. A atitude de ignorar doenças potencialmente curáveis no homem (ex.: varicocele) e prosseguir com a técnica da ICSI, como única opção para todos os problemas relacionados à infertilidade masculina, é uma atitude sem mérito, infundada e extremamente perigosa. Mesmo com resultados positivos, a ICSI continua invasiva, suprime os processos de seleção natural no momento da fertilização e, do ponto de vista custo-benefício, está muito aquém das opções de tratamento apropriadas para problemas de infertilidade masculina. A ICSI deve ser respeitada e é uma ferramenta útil do urologista para os casos de oligo ou azoospermia grave, após encerradas etapas mais simples. (HALLAK, s/d, p. 39)
\end{abstract}

A aplicação da ICSI para os casos nos quais não se justificaria seu uso, do ponto de vista médico e inclusive técnico, traria implicações imprevisíveis não só genéticas como também sociais e culturais. Alguns especialistas observaram que, antes de se discutir o tipo de técnica a ser aplicada, seria necessário fazer avaliações rigorosas sobre as causas da infertilidade, que deveriam ser informadas aos usuários de modo que eles estejam cientes das probabilidades de transmissão de doenças hereditárias aos seus descendentes. Tal posição, exposta por alguns especialistas (especialmente andrologistas e geneticistas), durante o Congresso de 2001, está explicita nas orientações da Sociedade Brasileira de Reprodução Humana, disponíveis na página eletrônica dessa entidade:

A introdução e a aplicação indiscriminada das técnicas de reprodução assistida vêm trazendo questionamentos e preocupações quanto ao risco de transmissão de doenças que de outra maneira seriam barradas pelo processo de seleção natural. Várias são as hipóteses aventadas para tal fenômeno: a) mecanismos seletivos que combatem os espermatozóides considerados morfologicamente anormais que atuam in vivo talvez não atuem de forma efetiva nos procedimentos in vitro; b) o ambiente hormonal in vitro talvez predisponha a alterações na meiose e mitose ocasionando aneuploidia cromossômica; e c) mutações podem resultar de várias exposições químicas e ambientais durante a fertilização in vitro.

A prevalência de malformações congênitas em crianças nascidas de ICSI parece ser superior quando comparada às crianças que nascem 
sem a necessidade da FIV, sendo de $3,78 \%$ vs. $7,38 \%$, respectivamente. A incidência de malformações geniturinárias, como criptorquidia e hipospádia é de 7 a 12 vezes superior com a ICSI comparada a crianças nascidas de gestações estabelecidas naturalmente. A incidência de aberrações cromossômicas sexuais é significativamente maior (0,3$1,6 \%)$ comparado com a população geral (0,19-0,23\%). Portanto, existem indícios fortes que há transmissão de malformações congênitas na população por meio da utilização da ICSI, devendo ser esta técnica utilizada quando os outros recursos terapêuticos falharam, e não como primeira opção. (PASQUALOTTO, s/d, p. 48-49)

A promoção de decisões informadas, nas quais sejam expostos abertamente os riscos mencionados por Pasqualotto, entre outros, poderia orientar as pessoas, por exemplo, a desistirem de realizar tratamento de RA e optar pela adoção de crianças. Cabe anotar que esta não foi uma alternativa frequentemente evocada entre especialistas em reprodução humana, pelo menos durante o período de análise desse campo, realizado entre 1999 e 2003 (RAMíREZ-GÁLVEZ, 2003).

Como observam Beck e Beck-Gernsheim (2003), não somente o corpo, mas a vida se tornou um fenômeno de tomada de decisões e de ações. Isto é, de escoIhas viabilizadas com o uso de tecnologia, que criam a ilusão de liberdade, uma vez que, no caso das tecnologias reprodutivas conceptivas, estas são apresentadas como possibilidades que abrem perspectivas no nível das opções reprodutivas, com as quais as famílias seriam livres para escolher a forma que irão assumir (STRATHERN, 1991). Contudo, pelo menos no caso do Brasil, parece que o acesso a tais tecnologias se coloca não só no plano da liberdade de escolha de dar à família a forma desejada, mas, também, no plano do direito a ter um fiIho próprio. Para alguns especialistas em RA, as tecnologias reprodutivas seriam uma opção e os casais teriam a liberdade e o direito de tentar um filho próprio, antes de adotar o filho de outros.

Como argumenta Strathern, o que as técnicas reproduzem é a opção dos pais, uma vez que a criança encarna o desejo dos mesmos de terem um filho. Isto é, remete-se a uma linguagem do direito para ter acesso ao uso de tecnologias que estariam disponíveis para atingir o que se deseja. Temos, então, como afirma a autora:

Por um lado uma visão fantasiosa de opções, por outro, a realização de decisões concretas: seja como for a maneira como se encare a questão, podemos agora pensar na procriação como algo que está sujeito a preferências e opções pessoais duma maneira que nunca anteriormente fora possível. A criança é literalmente - e em muitos casos, como é evidente, com grande alegria - a encarnação do ato de optar. (STRATHERN, 1991, p. 1013) 
6. Esse procedimento é descrito na página do Clínica e Centro de Pesquisa em Reprodução Humana Roger Abdelmassih do seguinte modo: "Recentemente, desenvolveu-se uma técnica que foi denominada "transferência de citoplasma", com o objetivo de aumentar a qualidade de um oócito, através da transferência de citoplasma extraído de um oócito "doador" de excelente qualidade para um oócito receptor com qualidade citoplasmática comprometida. Deste modo, a qualidade global do oócito melhora, aumentando as chances da implantação do embrião e de gravidez. (...) A restauração do potencial de desenvolvimento de oócitos incompetentes pode ser atingida pela alteração do estado molecular dos mesmos, utilizando a injeção de organelas selecionadas, ou através da transferência de citoplasma normal desprovido de material nuclear. Neste último caso, o oócito receptor torna-se híbrido do ponto de vista citoplasmático e, com isso, pode-se, hipoteticamente, restaurar parcialmente o estado fisiológico normal." Disponível em < http://www. abdelmassih.com. br/tr_transferencia_ citoplasma01.php>.
Contudo, o domínio da iniciativa não é mais extraído da referência do mundo natural - uma vez que a biologia sob controle deixa de ser natureza, como bem lembra a autora -, mas do domínio do mercado, como um cliente que procura serviços, nos quais o "produtor fabrica de acordo com as opções do consumidor e o consumidor compra de acordo com as opções que the são oferecidas pelo produtor" (ibidem, p. 1015).

Desse modo, temos um campo individualizado de decisões no âmbito moral e privado dos indivíduos que, além dos imperativos sociais de constituição familiar e dos processos de racionalização e de planejamento da vida, obedece ao mercado das opções tecnológicas, no qual o embodied progress, como veremos mais adiante, produz muito mais do que a procura de filho.

Trazendo à baila as questões discutidas por Beck e Beck-Gernsheim (2003), podemos considerar que a tecnologia reprodutiva, na sua inter-relação com a tecnologia e a genética, traz a dimensão do planejamento e da racionalização não só da sua vida, como dos descendentes, operando com duas dimensões altamente valorizadas: a da saúde e a da responsabilidade, com suas correspondentes reformulações contemporâneas, evitando, em princípio, nascimentos de crianças com algum tipo de limitação seja física ou genética. Concomitantemente, haveria que se considerar a dimensão higiênica, de seleção, operada no plano individual e os efeitos das mesmas em relação às crianças disponíveis para adoção.

Durante o V Congresso Brasileiro de Reprodução Assistida, o tema da responsabilidade pelas escolhas e pelo uso de certas técnicas foi debatido, especificamente, ao se mencionar a possibilidade da clonagem reprodutiva e os aspectos éticos envolvidos em outras experiências como a transferência de citoplasma ${ }^{6}$, um novo procedimento que fora anunciado, por esses dias, pelo médico Abdelmassih e divulgado amplamente na imprensa (LEITE, 2001a e 2001b; NATÉRCIA, 2001; Folha de S.Paulo, 05/05/2001)'.

As apreciações de uma das médicas que levantou tais questões foram na mesma direção de outras/os profissionais, como geneticistas e autores/as das ciências humanas e sociais, que apontam que o domínio quase integral das técnicas do saber científico poderia produzir uma sociedade totalitária, rumo à qual estaríamos atualmente. Beck (1998), citando Arendt, lembra que uma forma tirânica de dominação seria precisamente aquela pela qual a ninguém se pode atribuir a responsabilidade pelas consequências de uma ação. Dado o ineditismo de muitas dessas intervenções, a curiosidade e/ou o desejo de fazer tudo aquilo que é tecnicamente possível, o chamado gradualismo do uso das técnicas, poderia levar a sociedade a um ponto no qual não haveria retorno. Mas, nem sempre a tecnologia funciona como se deseja ou espera e, mesmo assim, 
estar-se-ia tomando atitudes apresadas com respeito a seu uso, do qual advém um grande problema de responsabilidade social, ligado à ausência de normas e leis que estabeleçam limites.

A experiência de transferência de citoplasma, ou "turbinação de óvulos" (como também aparece referenciado esse procedimento na mídia) precisaria, segundo os/as especialistas de, pelo menos, duas gerações para poder afirmar sua inocuidade. Perante esse questionamento colocado pela colega da mesa redonda, na qual o especialista Abdelmassih participara, o mesmo respondeu:

O que nós fazemos, sem dúvida, é fazer que haja um conhecimento do casal de que isso pode acontecer e (que) assine um documento sabendo desse conhecimento, de que pode haver uma interferência do DNA da doadora, do DNA doador para o citoplasma receptor (...) tem que haver a informação e a concordância do casal. (diário de campo) ${ }^{8}$

No entanto, outro foi o tom dado na mídia acerca do mesmo questionamento. Isto é, as duvidas com relação aos riscos trazidos pela presença de informação genética do pai, da mãe e da doadora de citoplasma ficaram abafados pela assertividade, convicção e autoridade do expert:

Para o médico Roger Abdelmassih, especialista em reprodução e pioneiro no uso da técnica no país, a transferência de citoplasma não traz riscos à saúde do bebê. Ele afirma que cerca de 50 crianças já nasceram por meio dessa técnica em sua clínica, e "todas elas são absolutamente normais". (Folha de S. Paulo, 27/08/2001, p. C7)

A assertividade, a convicção e o poder desse especialista parece que não ficaram abalados durante o congresso de 2001, apesar dos questionamentos feitos naquela ocasião por vários de seus colegas, também especialistas em reprodução humana. No entanto, não passa inadvertido, para essa pesquisadora, que o uso dessa mesma técnica foi referenciado entre as acusações de uso indevido de material genético, em $2009^{9}$. O que chama a atenção para a nossa análise acerca das questões, para além de simplesmente técnicas que perpassam a escolha pelo uso de certos procedimentos na reprodução assistida (como a seleção de sexo sem justificativa médica e a transferência de citoplasma, amplamente divulgados na mídia), é que os questionamentos éticos que envolvem a realização dos mesmos somente parecem ter ganhado relevância concomitantemente às acusações por estupro do Dr. Abdelmassih. Uma análise mais cuidadosa desse assunto, focalizando especialmente as implicações ou efeitos desse escândalo no campo da RA, associado ao principal divulgador de tecnologias reprodutivas no Brasil, seria matéria para outro artigo.

A seguir, retomamos nosso objetivo de considerar outros desdobramentos
7. Diga-se, de passagem, que o procedimento de transferência de citoplasma foi mencionado na telenovela O Clone, da Rede Globo, exibida originalmente entre 2001 e 2002. $\mathrm{O}$ debate acerca da presença de DNA mitocondrial da doadora no óvulo "híbrido" fora utilizado no enredo para definir, juridicamente, quem seria a mãe do sujeito clonado.

8. Para uma discussão sobre o uso de consentimento informado em procedimentos de RA e de seu uso para aceitação de intervenções cujos riscos não são esclarecidos, ver Menegon (2006).

9. Conferir, entre outras, a matéria: "Ex-colaborador denuncia pesquisas feitas em clínica de Roger Abdelmassih". 23/08/2009. Disponível em: <http://www.votebrasil.com/noticia/brasil-mundo/ ex-colaboradordenuncia-pesquisas-feitas-em-clinica-de-roger-abdelmassih>. 
possíveis ou desvios de função do uso de tecnologias reprodutivas que se fazem manifestas, ao considerar o campo de adoção de crianças.

4. De razões técnicas a efeitos simbólicos: o uso de tecnologias reprodutivas no contexto de adoção de crianças

A intervenção usada na reprodução médica e tecnologicamente assistida não procura reparar ou restabelecer uma função corporal. A técnica, em muitos casos, se consolida e consagra, ela mesma, como a função reprodutiva, introduzindo aqui um deslocamento do natural. Todavia, ainda que a biologia sob o domínio da técnica não é mais natureza (STRATHERN, 1991), continua-se a operar com um registro de naturalidade, no entanto, reinventado. O natural, aqui, não é mais a forma de nos reproduzirmos, mas o desejo de reproduzir com boa qualidade, isto é, de fazer uma reprodução qualificada: "sadia e responsável". Adicionalmente, a técnica não só substituiria uma função corporal, como também superaria a natureza ao tentar adaptá-la às demandas do mundo contemporâneo: remedia o declínio natural de fertilidade concomitante ao aumento da idade da mulher, ou torna possível a maternidade/paternidade biológica entre pessoas do mesmo sexo. Tais tentativas se configuram como uma espécie de domesticação ou adaptação da natureza às exigências do mundo contemporâneo, entre elas, à manutenção de corpos sempre jovens, manifesto, entre outras formas, na preservação da capacidade reprodutiva.

Na mídia e na publicidade dos centros de RA, que foram analisadas em trabalho anterior (RAMÍREZ-GÁLVEZ, 2003), as novidades tecnológicas nesse campo são apresentadas como um atrativo de elegibilidade que responde à representação, na tradição Iluminista, do avanço científico como inevitável, intrinsecamente progressivo e benéfico. Na divulgação da RA, observa-se a mobilização de convenções e valores tradicionais que evocam a concepção de filhos com material genético partilhado para a configuração de uma verdadeira família.

Na representação contemporânea da infertilidade, esta é concebida como um obstáculo ao processo de realização da identidade feminina e da conjugalidade, considerada "normal e natural" (FRANKLIN, 1997). Por sua vez, a tecnociência permitiria recriar a família na sua forma mais tradicional, realizando o desejo de ter filhos biológicos, o que exige certa disposição para encarar um processo com poucas possibilidades de sucesso. A realização de várias tentativas de RA, usando diversas técnicas, é característica desse meio (RAMíREZ-GÁLVEZ, 2007), assim como a ampliação de indagações tecnológicas e manipulações no nível dos gametas, na procura da perfeição biológica que visa, entre outros, controlar a qualidade do embrião (ROTANIA, 2001). 
As tecnologias reprodutivas conceptivas são colocadas em um leque de possibilidades de escolha, e o acesso às mesmas se coloca, como já foi dito, no plano dos direitos para gerar o filho próprio, investido de um profundo desejo que se faria manifesto na disposição do casal ou, mais especificamente da mulher, para fazer sacrifícios de diversa ordem: tanto de tolerar procedimentos altamente invasivos, como de pagar altos custos financeiros pelo tratamento. Adicionalmente, a escolha facilitada pelo uso da técnica seria apresentada nesse contexto como uma garantia da qualidade da descendência. Nesse panorama, cabe colocar, em perspectiva, a outra forma de solução "social" para a ausência involuntária: o processo de adoção de crianças, considerando suas relações possíveis com as tecnologias reprodutivas.

O rápido crescimento e a consolidação da RA no Brasil apontariam para um cenário no qual, pelo menos entre certos segmentos socioeconômicos, a adoção não seria promovida como uma possibilidade também desejável para resolver a ausência involuntária de filhos (RAMíREZ-GÁLVEZ, 2007). Ao contrário, os casais cuja infertilidade ainda não pode ser resolvida com a tecnologia disponível são estimulados a continuar à espera do acelerado desenvolvimento tecnológico que, teoricamente, derrotaria todas as formas de infertilidade. O termo adoção, até pouco tempo reservado para aludir à adoção de crianças, ampliou-se nesse contexto para referir-se, também, à adoção de gametas e de embriões. Os desenvolvimentos tecnológicos na reprodução humana permitem a possibilidade de adoção, em estágios mais primários da reprodução, inclusive no nível das células microscópicas, às quais, em muitos casos, Ihes é atribuído o sentido de "filho", de pessoa, como neste depoimento de uma médica de 48 anos:

Eles estavam dentro de um tubo de ensaio. Tudo o que se via era a gotinha cor-de-rosa do soro anticoagulante sobre os embriõezinhos. Eles estariam mofando num freezer se eu não os tivesse tirado de lá. Eu os alimentei dentro do meu útero durante nove meses. Eles não existiriam sem o meu corpo. (CARELLI, 2001)

Mesmo na impossibilidade de reprodução com o próprio material genético, as experiências corporais de gravidez, de parto e de amamentação são destacadas como essenciais à "identidade" feminina, viabilizadas apenas mediante o uso da RA, mas não pela adoção de crianças, cuja experiência estaria mais voltada à vivencia do cuidado, de maternar uma criança, após alguns dias, meses ou anos de seu nascimento.

Ao se colocar o uso dessas tecnologias, por parte de alguns especialistas em RA, no plano do direito de tentar um "filho próprio" (RAMÍREZ-GÁLVEZ, 2003) e de procurar o controle da biologia, visando a eliminação de traços e característica indesejadas dos descendentes, poderíamos considerar que há uma atribuição 
10. Maiores especificidades desses dados foram explicitadas em outro artigo (RAMÍREZ-GÁLVEZ, no prelo) e no relatório da pesquisa Exclusões e deslocamentos. Reprodução assistida $e$ adoção de crianças (RAMÍREZ-GÁLVEZ, 2006). Embora essa pesquisa contemple dados mais abrangentes sobre o campo de adoção de crianças, os que se apresentam aqui restringem-se aos processos de habilitação, no intuito de estabelecer o diálogo com a RA. de valor a um e outro modo de se ter filho. Por outro lado, observamos, no momento atual, uma valoração da genética como definidora e constitutiva não só da saúde, mas de uma série de outras características humanas. Nesses termos, é possível conjeturar ou pressupor que, cada vez mais, a adoção de crianças é deslocada como uma opção desejável, entre alguns sectores socioeconômicos, reforçando os supostos medos e riscos inerentes à introdução de um estranho no ninho - isto é, de uma linhagem genética diferente.

Essa forma biotecnológica de encarar e abordar a solução do problema da infertilidade involuntária nos coloca no plano de procura de soluções individualizadas e privatizadas, feitas no contexto do consultório-laboratório, no qual o médico arroga a si o controle do processo, submetendo-o à sua lógica, mediada por uma racionalidade individualizada e abrindo margem, como afirma Strathern (1992), à proliferação de inúmeros desejos, cuja realização é habilitada pela capacidade econômica que possibilita o acesso ao uso de tecnologia.

À vista desse panorama, no qual muitos dos especialistas em reprodução humana parecem se restringir às "razões técnicas", realizando a "implementação tecnológica como experimento" a qualquer custo e se abstraindo da lógica da precaução da descoberta científica - que supõe o experimento antes da aplicação - , cogita-se que a RA se esteja configurando como uma alternativa valorizada e amplamente divulgada para resolver a ausência involuntária de filhos. Resulta pertinente, então, indagar quais os efeitos desse imaginário no campo da adoção de crianças. Ao formular tal hipótese não desconsideramos que a adoção de crianças continue sendo uma possibilidade, no entanto, o que propomos é que tal possibilidade pareceria ser protelada até a realização de múltiplas tentativas fracassadas com varias técnicas.

Tal hipótese está baseada na análise de 25 processos de pedido de adoção, aprovados no Fórum de Santo Amaro (São Paulo), cujos solicitantes esperavam pela colocação de uma criança, no ano de 2006. Dentre os 25 processos, temse 21 casais, sendo que quatro correspondem a habilitações de mulheres sós. Esses dados foram complementados com observações realizadas, entre 2004 e 2006, em três grupos de apoio à adoção do Estado de SP (dois da capital e um de Campinas) e com entrevistas informais com frequentadoras/es e voluntárias/ os desses grupos ${ }^{10}$.

Como foi possível apreciar na análise dos processos de casais habilitados para adoção, com maiores rendimentos econômicos, a procura pela adoção de crianças se realizou após várias tentativas de reprodução assistida, ao longo de alguns anos. Isto é, o projeto de adoção foi iniciado somente após considerar esgotadas as possibilidades de conceber um filho biológico. Embora, a adoção já tivesse sido concebida como uma alternativa possível, alguns casais reportaram 
a necessidade de tentar e esgotar a possibilidade de ter um filho biológico como uma forma de amadurecer e consolidar essa opção.

\section{A função simbólica da RA no processo de adoção}

Ter filhos aparece como determinante para a conformação de uma "verdadeira" família. Um casal sem filhos aparece como uma família incompleta e estes começam a ser "procurados", especialmente após uma estabilidade financeira e profissional. Como indica Fonseca (1995), para a classe média, o modelo de família está centrado na família conjugal, na qual as crianças são o resultado de um projeto de longo termo, que se torna foco da unidade conjugal.

À exceção de um dos processos analisados, em cujo caso a motivação por adotar uma criança não estava atrelada à infertilidade, em todos os outros, a procura pela adoção de uma criança foi determinada pela impossibilidade de engravidar. Na maioria das vezes, a infertilidade foi diagnosticada medicamente, reportando-se entre 10 dos 21 casais solicitantes o uso de tecnologias reprodutivas conceptivas, como a Inseminação Artificial e a Fertilização in-vitro. Em alguns casos, o tratamento médico-tecnológico foi abandonado rapidamente por considerá-lo muito caro e invasivo ou por avaliar que havia poucas perspectivas de sucesso. A persistência de tentativas para ter um filho com o uso de RA foi mais predominante entre os casais com maior renda familiar. Verificamos que, em tais casos, se realizaram entre 3 e 6 procedimentos de RA, reportando-se, no inicio, o uso de procedimentos considerados de baixa complexidade, como a Inseminação Artificial, até chegar na FIV e na ICSI. Esse processo de repetição de procedimentos e passagem para o uso de técnicas consideradas mais complexas pressupõe a disposição desses casais, como também disponibilidade financeira, para permanecerem nessa busca por um longo período de tempo que, nos processos analisados, chegou ao máximo de sete anos.

Dado que não houve contato direto com esses casais e que a informação está circunscrita, visando ao processo de habilitação, limitamo-nos aos dados que compõem os dossiês do Fórum, fornecidos tanto pelo casal solicitante, como pelas análises e avaliações dos/as operadores/as da justiça. Mais especificamente, das avaliações psicossociais realizadas por assistentes sociais e psicólogas. O que interessa destacar aqui é a importância dada, especialmente pelas operadoras de justiça, à função atribuída às tentativas de RA, que parecem se configurar como um ato simbólico, cuja função seria a de saber que as possibilidades de se ter um filho biológico estariam esgotadas. Essa convicção parece ser considerada como essencial para que a adoção seja considerada um projeto maduro e bem sustentado. 
Embora a adoção de crianças fosse mencionada como uma possibilidade, antes, de se constatar a infertilidade, reporta-se a necessidade de tentar e saber, esgotadas as possibilidades, de ter um filho biológico, como uma forma de amadurecer e consolidar essa opção. Percorrer todos os caminhos e opções para ter um filho biológico, o que atualmente implica ter recorrido ao uso de tecnologias reprodutivas, parece ganhar outro significado: o de indicador do amadurecimento do projeto de adoção. Mesmo entre os/as operadores/as desses serviços, e em contraposição ao surgimento do discurso de uma nova cultura da adoção, pode-se afirmar a naturalização do desejo de filhos consanguíneos. Isto é, o que parece ser uma constante é a necessidade de elaborar o luto pelo filho biológico como condição para iniciar o processo de adoção. Em outras palavras, poderse-ia dizer que essa possibilidade parece ganhar corpo verdadeiramente e se consolidar somente após renunciar à possibilidade de filho biológico.

Para entendermos tal questão, uma vez que um de nossos pontos de partida é o estranhamento do desejo naturalizado de filhos biológicos, Franklin (1997) fornece interessantes elementos para análise. Segundo a autora, a procura por procedimentos de RA, especialmente por parte das mulheres, estaria orientada por alguma outra questão, que não apenas o desejo de filho: buscar solução ao problema da infertilidade, uma vez que a mesma se configura como um obstáculo à progressão, considerada "normal e natural", da conjugalidade e da identidade feminina. Para essa autora, as pessoas estariam cientes da brecha existente entre a esperança de sucesso e as possibilidades reais de alcançar o desejado filho, mediante as tecnologias reprodutivas. Assim, as expectativas estariam mais próximas da ambiguidade e da contingência do que da certeza; da superação de obstáculos que conduzam à resolução do drama da infertilidade de acordo com as normas convencionais de unidade da função conjugal e procriativa.

Nessa perspectiva, a RA teria a função simbólica de um ritual que permitiria sair de uma situação limiar criada pela infertilidade. Isto é, uma função de passagem, cada vez mais comum, para se assumir como uma mulher ou um casal sem descendência consanguínea, sem possibilidade de perpetuar seu patrimônio genético. O que interessa aqui considerar, como aponta Peirano (2003), é a função do ritual de transmitir valores e conhecimentos que, para além de resolver conflitos ou uma situação problemática em si, reproduz relações sociais que, nesse caso específico, atribui um lugar fundamental e habilitador à técnica. É aqui que nos interessa considerar que a RA ganha um espaço de atuação que transcende a sua função técnica, uma vez que ela não somente se torna um meio habilitador para ter "filhos próprios", mas também, no sentido manifesto nas linhas anteriores, um habilitador para adotar os "filhos dos outros". 
A RA se configura como uma das manifestações dos processos de mudança social, através dos quais a objetivação do ser humano é realizada por ele próprio, cuja alteração ou modificação da estrutura material da espécie é atingida, pela primeira vez, mediante a intervenção tecnológica (ROTANIA, 2001). Trata-se de um estágio de desenvolvimento tecnológico de extraordinário poder do homem sobre a natureza. Segundo Rabinow (1999), nesse estágio, a cultura deixa de ser uma metáfora da natureza, para adentrarmos num processo no qual a natureza é refeita através da técnica; a natureza se tornará artificial, assim como a cultura se tornou natural. No entanto, o que parece permanecer é a necessidade de manter vigente uma metáfora em algum elemento tido como natural. Como foi anotado antes, o natural não é mais o modo de ter filhos, mas sim o desejo de tê-los, encravado no imperativo social de "famílias verdadeiras ou completas", configuradas a partir da conjugação do sangue ou do capital genético do par conjugal (seja este ou não heterossexual) ou, de pelo menos, algum dos cônjuges.

Uma conclusão dessa análise que coloca esses dois campos em perspectiva, tomando como ponto de inflexão o lugar que a técnica ocupa em cada um deles, e que ainda precisa de maiores elaborações, coloca duas questões fundamentais: por um lado, a incorporação da tecnologia com novos desdobramentos de aplicação, nos quais a sua função ritualística abre nicho de mercado, expandindo seu uso para além da produção de bebês. Por outro lado, nas possibilidades introduzidas pela tecnologia, como a adoção de embriões, radicalizam-se desejos observados e amplamente documentados na literatura sobre a adoção de crianças: procura de bebês recém-nascidos ou de crianças muito pequenas, com características físicas similares à dos pais adotantes; processos nos quais, segundo Costa (1988), a procura pela parecença se configura como um ideal a ser atingido e, em certa medida, uma condição para que a adoção seja bem sucedida.

Nos casos em que não há possibilidade de reprodução assistida com o material genético próprio, a solução oferecida é a adoção de pré-embriões que, a partir da experiência corporal da gravidez, permitiria apagar ou domesticar as marcas de uma origem desconhecida, mas que poderia ser escolhida. A inscrição das marcas que orientam tais escolhas estariam na pele (cor), no formato de cabelo, etc., no caso da adoção de crianças, ou nos genes, no caso da adoção de pré-embriões. Em um e outro caso, está em jogo a promoção de escolhas que tomam como referência a reprodução biológica, procurando evitar a inclusão de um estranho no núcleo familiar. Mesmo quando se aceita a inclusão de alguém cuja procedência é desconhecida, não deixam de se mobilizar estratégias para mimetizar ou domesticar a diferença, de modo a não deixá-la tão evidente. 
O discurso científico se torna uma via para reforçar estereótipos, como os de gênero e raça/cor concebidos, corriqueiramente, como tendências "naturais" evocados para representar uma realidade como sendo natural, objetiva e verdadeira. As explicações baseadas na natureza ou em habilidades naturais servem para colocar pessoas nos contextos desejados, excluindo-os, por sua vez, de outros (NELKIN \& LINDEE, 1995).

Se, na RA, há a busca de soluções no plano privado que afetam o social, no plano da adoção, procura-se uma solução privada projetada no bem público. Interessa politizar esse diálogo e dirigir o olhar para as consequências da radicalização da satisfação de um ideal, da afirmação e satisfação de um desejo individual em detrimento do bem público, da exacerbação do desejo individual, que abre espaço para todos os gostos e cria mais excluídos/as.

A tecnologia reprodutiva parece constituir o principal operador e habilitador para atingir desejos naturalizados que reforçam a maternidade como essencial à realização feminina. A experiência corporal da maternidade é destacada para justificar a existência de programas de adoção de embriões ou o desenvolvimento de técnicas que permitam a concepção em idade avançada, em uma tentativa de superar e expandir os limites de uma natureza que teria ficado pequena para dar conta do mundo contemporâneo.

A RA, vista a partir da sua função simbólico-ritual, para superar o limbo criado pela infertilidade, parece ganhar território ao se constituir em um meio contemporâneo para resolver ou se assumir definitivamente infértil. Quer dizer, a sua função deixa de ser estritamente técnica, passando, nesses casos, a ser simbólica e, como antes foi dito, uma forma de certificação de se estar pronto para adoção, configurando mais um nicho de mercado para seu uso.

Abstract: Technological options are also political options, but the political implications of technological options are obscured by discourses, practices and decisions that present themselves as strictly technical. When considering the case of assisted reproduction (AR), we observe that the scientific development is presented as a technical response to a "natural and atavistic" wish to go through the bodily experience of pregnancy, childbearing and nurturing, anchored in the naturalization of the desire for reproduction. However, such questions are reconsidered in this article due to the specificity and singularity of the field. For our analysis, we examine AR and adoption. Preliminary results show that $A R$ procedures have had further developments besides the acquirement of a child, gaining a new market niche: the symbolic function of elaborating the mourning for the biological child, considered necessary for maturing the project of child adoption.

Keywords: Assisted Reproduction, Biotechnology, Adoption, Market. 


\section{Referências Bibliográficas}

ABDELMASSIH, Roger. Tudo por um bebê. São Paulo: Globo, 1999.

BECK, Ulrich. "Sobre a incompreendida falta de experiência da genética humana e as considerações sociais do não-saber relativo" In: L. A. De Boni, G. Jacob, F. Salzano. Ética e genética. Porto Alegre: EDIPUCRS, 1998, p. 39-62.

BECK, Ulrich \& BECK-GERNSHEIM, Elisabeth. "La salud y la responsabilidad en la era de la tecnología genética" In: La individualización. El individualismo institucionalizado y sus consecuencias sociales y políticas. Barcelona: Paidós Ibérica, 2003.

BERLINGUER, Giovanni; GARRAFA, Volnei. A mercadoria final: a comercialização de parte do corpo humano. Tradução: Isabel Regina Augusto. Brasília: Editora Universidade de Brasília, 2001.

BOURDIEU, Pierre. "O campo científico" In: R. Ortiz (org.) Pierre Bourdieu. São Paulo: Ática, Coleção Grandes Cientistas Sociais, 1994.

CARELLI, Gabriela. "Tudo por um filho. Com ajuda de casais dispostos a se arriscar, a ciência esta vencendo a infertilidade", Veja, Edição 1699, p.108-115, Maio 9, 2001.

Clinica e Centro de Pesquisa em Reprodução Humana Roger Abdelmassih. Transferência de citoplasma. Disponível em: <http://www.abdelmassih.com.br/ tr_transferencia_citoplasma01.php> Acesso em: 20 fev. 2011.

COSTA, Maria Cecília. Os filhos do coração: adoção em camadas médias brasileiras. Rio de Janeiro. Tese (Doutorado em Antropologia) - PPGAS/Museu Nacional, UFRJ, 1988.

CROISSANT, Jennifer; RESTIVO, Sal. "Science, social problems, and progressive thought: essays on the tyranny of science" In: S. L. Star (ed.) Ecologies of knowledge: work an politics in science and technology. USA: State University of New York Press, 1995.

EUA têm bebês "geneticamente alterados". Folha de S. Paulo. São Paulo, Maio 5, 2001. Ciência. p.A15.

Ex-colaborador denuncia pesquisas feitas em clínica de Roger Abdelmassih. 23/08/2009. Disponível em: <http://www.votebrasil.com/noticia/brasil-mundo/ ex-colaborador-denuncia-pesquisas-feitas-em-clinica-de-roger-abdelmassih>. Acesso em: 13 out. 2010 
FONSECA, Claudia. Caminhos da adoção. São Paulo: Editora Cortez, 1995.

FRANKLIN, Sara. Embodied Progress. A cultural account of assisted conception. London and New York: Routledge, 1997.

HALLAK, Jorge. Riscos de transmissão à prole com uso de reprodução assistida em infertilidade masculina, Mimeo, 2000.

. Azoospermias não-obstrutivas. Diagnóstico e conduta. s/d. Disponível em: <http://www.sbrh.org.br/guidelines/guideline_pdf/guideline_de_ andrologia.pdf> Acesso em: 20 fev. 2011.

KASPER, Christian Pierre. "Desviando Funções". Nada. Lisboa, n. 5, 2005, p. $72-$ 77

LEITE, Eduardo. EUA debatem "reforma" de óvulo humano. Folha de S. Paulo. São Paulo, Maio 4, 2001a (Ciência. p. A17) . Os tais bebês "transgênicos". Folha de S. Paulo. São Paulo, Maio 10, 2001b. (Opinião. p. A2)

MENEGON, Vera. Entre a linguagem dos direitos e a linguagem dos riscos: os consentimentos informados na reprodução humana assistida. São Paulo: Fapesp, Edusc, 2006.

NATÉRCIA, Flavia. Alterar óvulo não é engenharia, diz médico. Folha de S. Paulo. São Paulo, Junho 1, 2001. (Ciência. p.A12)

NELKIN, Dorothy; LINDEE, Susan. "The media-ted gene. Stories of gender and race" In: J. Terry, J. Urla. Deviant bodies. Critical perspectives on difference in science and popular culture. Bloomington and Indianapolis: Indiana University Press, 1995.

OUDSHOORN, Nelly. Beyond the natural body. An archeology of sex hormones. London and New York: Routledge, 1994.

PASQUALOTTO, Firmbach Fábio. Genética e infertilidade masculina. s/d. Disponível em: <http://www.sbrh.org.br/guidelines/guideline_pdf/guideline_de_andrologia.pdf> Acesso em: 20 fev. 2011.

PEIRANO, Mariza. Rituais ontem e hoje. Rio de Janeiro: Jorge Zahar Ed., 2003.

RABINOW, Paul. "Artificialidade e lluminismo: da sociobiologia à biossociabilidade" In: Antropologia da razão: ensaios de Paul Rabinow. Organização e tradução de João Guilherme Biehl. Rio de Janeiro: Relume Dumará, 1999. 
RAMÍREZ-GÁLVEZ, Martha Celia. Novas tecnologias reprodutivas conceptivas: fabricando a vida, fabricando o futuro. Tese (Doutorado em Ciências Sociais) IFCH/UNICAMP, Campinas, 2003.

. Exclusões e deslocamentos. "Reprodução assistida e adoção de crianças". Relatório de pesquisa. Programa de Formação de Quadros Profissionais (2004-2006) Centro Brasileiro de Análise e Planejamento - CEBRAP. São Paulo, 2007.

. "Inscrito nos genes ou escrito na estrelas?: Adoção de crianças e uso de Reprodução Assistida" Revista de Antropologia - USP, no prelo

Rotania, Alejandra. "Entre o sangue e o gesto. Reflexões sobre as NTRc e a adoção" Congresso De Bioética Da América Latina E Caribe. São Paulo, Outubro, Mimeo, 1995.

. "Biologia moderna, feminismo e ética" In: L. Scavone (org.) Tecnologias reprodutivas: gênero e ciência. São Paulo: Editora da Universidade Estadual Paulista, 1996.

. A celebração do temor. Biotecnologias, reprodução, ética e feminismo. Rio de Janeiro: E-papers, 2001.

SANTOS, Laymert Garcia. "Invenção, descoberta e dignidade humana" In: F. Carneiro, M. C. Emerick (orgs.) Limites: a ética e o debate jurídico sobre o acesso e uso do genoma humano. Rio de Janeiro: Ministério da Saúde e Fundação Oswaldo Cruz, 2000.

. “Apresentação". Cienc. Cult. São Paulo, v.60, n.1, 2008, p. 24-25,

STRATHERN, Marilyn. "Parentesco por iniciativa: a possibilidade de escolha dos consumidores e as novas tecnologias de reprodução". Análise Social. Vol.XXVI (114) [sic], (5ㅇ), 1991, p.1011-1022. Disponível em: <http://analisesocial.ics. ul.pt/documentos/1223043256I1gUW3nr3Dk90CT1.pdf>

. Reproduction the future: essays on anthropology, kinship and

the new reproductive technologies. Manchester, Manchester University Press, 1992. 